\title{
AS CAUSAS DE REDUZIDO VALOR ECONÔMICO E O SEU TRATAMENTO NO DIREITO LUSO-BRASILEIRO: O JUIZ DAS VINTENAS; O ALMOTACÊ; O JUIZ DE PAZ
}

\author{
Luiz Carlos de Azevedo \\ Professor Doutor do Departamento Processual da Faculdade de Direito da USP
}

\begin{abstract}
Resumo: Entre os cargos da administração judicial e extrajudicial nas Ordenaçōes do Reino incluíam-se alguns que tinham por finalidade julgar as causas de reduzido valor econômico. Assim, o juiz das vintenas e o almotacê. $O$ primeiro, escolhido entre os homens bons da aldeia, decidia rapidamente os litígios, sem sobre eles "fazer processo", com alçada até 400 réis. $\mathrm{O}$ segundo, que traz antiga origem, a qual no corpo do trabalho se descreve, possuía inúmeras atribuiçōes, tanto administrativas, quanto judiciais. No Brasil, a Carta Constitucional de 1824 criou o juiz de paz, devendo este tentar conciliar as partes e decidir as causas, cujo valor não excedesse a $16 \$ 000$, vigiar a conservação das matas, etc. Foram institutos criados nas legislações anteriores, com o propósito de permitir o acesso à justiça das pessoas, mesmo as mais humildes.
\end{abstract}

Résumé: Parmi les fonctions de l'administration judiciaire e extrajudiciaire on trouvait dans les Ordenations du Royaume quelques-unes qu'avaient comme but juger les demandes qu'avaient une petite valeur economique comme celles de juge des vingtaines et “altomacê". Le juge des vingtaines, choisi parmi les hommes bons du village, decidait rapidement les conflits, sans "faire de la procedure", avec juridiction jusqu'a 400 "réis" (l'argent de l'époque). "L'almotacê" avec origine ancienne, avait plusieurs fonctions, soit administratives, soit judiciaires. Au Bresil, la Constitution de 1824 a cré le juge de paix qui devait essayer la conciliation des parties en conflit et decider les demandes, dont la valeur n'était superieure à $16 \$ 000$, et encore surveiller la conservation des fôrets, etc. C'étaient des instituts crées par textes anterieurs avec le but de pourvoir l'accès à la justice des personnes, surtout les plus simples.

Unitermos: Juiz das Vintenas; Almotacê; Juiz de paz.

1. As Ordenaçōes Filipinas, a exemplo das anteriores, vinham divididas em cinco livros, cuidando o primeiro, em especial, de todos os magistrados e demais cargos da administração judicial e extrajudicial.

Ali se descrevem, em pormenores, as atribuições destes funcionários, partindo dos mais elevados, como o Regedor da Casa da Suplicação, o ChancelerMor, os Desembargadores do Paço e da mesma Casa, os Corregedores, e ou- 
tros, para chegar aos mais simples, como os meirinhos, carcereiros, porteiros e pregoeiros.

Incluem-se no rol outras relevantes funçōes, imprescindíveis também ao regular exercício da Justiça e da Administração: Procuradores do Conselho, Curadores, Advogados, Tabeliães, Escrivães, Vereadores.

Entre os magistrados, que muitos eram, encontram-se alguns cujas funçōes, nem sempre unicamente judiciais, revelam a preocupação do legislador da época, no sentido de dar tratamento mais aligeirado aos feitos, dispensando-se formalidades ou praxes tão comuns àquele mesmo período.

$\mathrm{Na}$ verdade, este cuidado ascendia a tempos ainda mais antigos, provindo do próprio Direito Costumeiro, no qual já aparecia o intuito de fornecer pronta Justiça aos comunheiros e habitantes das vilas e povoados, sem que lhes estorvassem maiores empecilhos ou se lhes exigisse provisão de dispendioso numerário.

2. Assim, a par dos juízes ordinários, eleitos pelos homens bons do Conselho, mais confirmação real; e a par dos juízes de fora-parte, designados diretamente pelo soberano, vamos encontrar, também, o juiz das vintenas, incumbido de julgar as causas, nas aldeias menores, afastadas uma légua ou mais das cidades ou vilas, e que contassem com pelo menos vinte vizinhos, ou vinte "fogos", como se costumava dizer.

Este homem bom da aldeia, após haver prestado juramento perante à Câmara, "conhecia e determinava verbalmente as contendas" que ocorressem entre os seus moradores, sendo a alçada fixada segundo o número de vizinhos, até no máximo quatrocentos réis; e tudo "sem apelação, nem agravo" e "sem sobre isso fazer processo". (ORD. FIL. LIV. I. TIT. LXV, § 73)

Embora de limitada jurisdição, pois lhes era vedado conhecer das causas nas quais se litigasse sobre bens de raiz, e assim também das causas criminais, o juiz das vintenas deve ter bem servido em sua época aos interesses da comunidade, pois Cândido Mendes de Almeida, em breve anotação que faz ao parágrafo mencionado, lamenta tenha sido a instituição aniquilada pela nova organização judiciária do Império, pois era ela "mais uma das facilidades que o antigo Direito Costumeiro outorgava aos povos na decisão das pequenas demandas, poupando-lhes fadigas e despesas, concorrendo os queixosos às povoações em procura de juízes, advogados, etc.". (Código Filipino ou Ordenaçōes e Leis do Reino de Portugal, Rio, 1870, tip. do Inst. Filomático, pg. 144).

3. Outra interessante figura deste elenco, é o almotacê.

Era este um oficial do Concelho, que tinha a função de fiscalizar o abastecimento dos gêneros alimentícios e os seus preços, controlar pesos e medidas, 
percorrer a vila e zelar pela sua limpeza e ordem; (a respeito, Ruy d'Abreu Torres, verbete in "Dicionário de História de Portugal", Porto, 1971, pg. 121) já desde 1145 as posturas municipais dele dão conta, ressaltando Herculano "que o objeto principal do cargo era a polícia do comércio interno do município e o impedir as falsificaçōes na grosseira indústria fabril daquela época". (Alexandre Herculano, "História de Portugal", Lisboa, 1916, Aillaud e Bertrand, Francisco Alves, Liv. VIII, parte II, pg. 319).

Mas as suas atribuições, como se verá, iam muito além do simples controle, isto porque, além dos encargos administrativos, também lhe assomavam poderes jurisdicionais.

O nome almotacé provém do árabe, "almuhtasib" ou simplesmente "muhtasib", "inspetor do mercado", (e este, de "haçaba", contar, calcular) já que existia este cargo na administração muçulmana, tendo passado à península ibérica quando da invasão.

Mas, na sua origem ainda mais remota, traz correspondência com o "praefectus annonae", do Império e com os "aediles curules" da República Romana; pois a estes também coubera exercer a polícia e jurisdição dos mercados, controlando as vendas e verificando pesos e medidas; e além destas funçōes administrativas, dispunham de certos poderes jurisdicionais, tanto que prendiam malfeitores e julgavam infraçōes menores, denunciando aos cônsules aquelas de maior gravidade (cf. Jean Gaudemet "Institutions de l'antiquité", Paris, 1967, Sirey, pg. 348; nas fontes, Cícero, "De legibus", III, 3, 7; Digesto, 1, 2, 2, 26, 48, 2, 13; Códice, 1, 4, 4).

No seu trabalho sobre o direito islâmico, Joseph Schacht encontra um elo importante no encadeamento destas idéias: quando do início da expansão islâmica, e ainda no Oriente Médio, os magistrados bizantinos, bem como os oficiais da administração das cidades conquistadas, al landonam as províncias aos invasores. Mas, pelo menos um cargo da administração local, que reunia também funções jurisdicionais, posto que limitadas, parece ser adotado pelos invasores: é o cargo de "inspetor de mercados" ("agoranómos"). ("An Introduction to Islamic Law", Oxford, 1964, At the Clarendon Press, pg. 25). Daí o "muhtasib" e, a seguir, o nosso almotacé.

As Ordenações Afonsinas já prescreviam as atribuiçōes destes oficiais, (ORD. AF. LIV. TIT. XXVIII $§ \$ 1$ a 23) mas a codificação seguinte acrescentou um rol de outras tantas tarefas, entre as quais aquelas de conhecer das demandas "que se fizerem sobre o fazer ou não fazer de paredes de casas, ou quintais, e assim de portais, janelas, frestas ou eirados"; (ORD. MAN. LIV. I, TIT. XLIX, § 24) dispondo, enfim, e largamente, sobre todo o direito de vizinhança. ( $\$ 25$ e segs.) 
Todos estes feitos deveriam ser "livrados bem e diretamente", "com brevidade, sem processos e grandes escrituras", decidindo o próprio almotacé sobre as apelaçōes e agravos nas causas que não excedessem a quantia de seiscentos réis. (ORD. MAN. LIV. I, TIT. XLIX, § 19; ORD. FIL. LIV. I, TIT. LXVIII, § 2)

3. Finalmente, o juiz de paz, criado, entre nós, pela Carta Constitucional de 1824.

Esta idéia de preservação da paz parte dos confins da História: e vamos encontrá-la tanto na "pax romana", quanto entre os povos germânicos; para estes, possuía a paz um sentido amplo e transcendental; "fridr", significava o conjunto de todas as forças provindas do mais íntimo da natureza, atuando no âmbito das inúmeras "sippen", ou famílias germânicas, de modo a influir decisivamente naqueles que a integravam. (cf. Marco Scovazzi, "Scritti di Storia del Diritto Germânico, Milão, 1975, Guiffré, vol. I, pg. 202)

Assim, embora notoriamente conhecidos como um povo guerreiro e individualista, traziam os germânicos impregnado em suas consciências um sentimento coletivo e igualitário de bem-estar do grupo a que cada um de seus membros pertencia, tudo com vistas a atender ao objetivo maior, isto é, à manutenção da paz.

Violá-la, seria atentar contra os interesses da "sippe", seria incidir na mais grave das faltas, a qual trazia, por conseqüência, severa punição, equivalente à pena capital: o culpado era banido da comunidade. (Scovazzi, op. cit., vol. II, pg. 125)

No primitivo direito 11 lsitano, esta mesma idéia persiste junto às comunas e povoados. Cada qual possuía sua carta ou diploma, onde se inscreviam os direitos e deveres coletivos dos habitantes da aldeia ou vila, as relaçōes entre estes habitantes e a entidade outorgante e todas as demais regras referentes ao direito público local (cf. Guilherme Braga da Cruz, História do Direito Português, Coimbra, 1955, pg. 297)

Mas, todo este direito vinha arraigado no costume, onde repercutiam traços visíveis da ascendência germânica. A própria vida jurídica local ia buscar assento no concelho, onde se reuniam os homens bons, aptos a atender aos interesses da comunidade, conhecendo e decidindo, também, a respeito das eventuais controvérsias então suscitadas. E este concelho nada mais era senão a constância e repetiçāo do antigo "mallum", ou assembléia germânica, pois ali se inspirara e nos seus moldes funcionava. (A respeito, Paulo Merea, "Organização Social e Administração Pública", in "História de Portugal", Barcelos, 1929, Portucalense Ed. Ltda., pg. 512) 
E persistia, então, a idéia de paz, aparecendo na "paz de el-rey", que proibia se cometessem violências por onde este passassse, quando da marcha itinerante que de hábito empreendia pelos seus domínios; (lei de D. Dinis, 1318, no Livro das Leis e Posturas, fl. 62, $1^{\text {a }}$ coluna, na edição publicada, pg. 190) na paz do concelho, do mercado, da igreja, e mais ainda, na paz da casa, onde se ressaltava a inviolabilidade do domicílio: "nenhum nom va aa herdade de nenhũm homem nem a ssa casa pera lhi fazer mal". (Lei de D. Dinis, 1303, Livro das Leis e Posturas, fls. 22vo

No entanto, a expressão "juiz de paz", ao que consta, não aparece a esse tempo no direito lusitano e nem mesmo mais tarde.

Ela é oriunda do direito inglês, onde também se cuidou de preservar a paz nos condados, durante a Idade Média. E tal intuito, embora remonte a anos anteriores, vem expressamente reafirmado com Eduardo III, em 1327. (Sir William Holdswork, “A History of English Law, Londres, 1969, Methuen e Co. Ltda., Vol. I, pg. 287)

No Brasil, a organização judiciária, até a Independência, seguia os moldes das disposições reinóis. Com a proclamação, embora permanecessem em vigor as Ordenaçōes Filipinas, outras idéias vieram se incorporar ao direito da nação nova; e a Constituição Política do Império, de 25 de março de 1824 determinava que "sem se fazer constar que se tem intentado o meio de reconciliação, não se começará processo algum". (art. 161) "Para este fim, haverá juízes de paz, os quais serão eletivos pelo mesmo tempo e maneira que se elegem os vereadores das Câmaras". Suas atribuições, veio fixá-las na lei de 15 de outubro de 1827: entre outras, cabia-lhes conciliar as partes que pretendem demandar, por todos os meios pacíficos que estiverem ao seu alcance, julgar pequenas demandas, cujo valor não exceda a $16 \$ 000$, fazer separar os ajuntamentos, em que há manifesto perigo de desordem, fazer que não haja vadios e providenciar para que não se formem quilombos, vigiar sobre a conservação das matas e florestas públicas e obstar nas particulares o corte de madeiras reservadas por lei, compor as contendas e dúvidas entre os moradores do distrito acerca de caminhos, passagem, águas, limites, tapagens e cercados, etc.

Lei de 11 de outubro de 1837 irá dar-lhes o conhecimento de todas as açōes derivadas de contratos de locações de serviços, competência que será mantida pelo Decreto de 15 de março de 1842; do mesmo modo, conhecerão e decidirão as causas da almotaceria que não excederem a sua alçada, na forma do Dec. de 26.8.1830 e Lei de 3.12.1841.

No entanto, ainda no Império, como na República, a competência do juiz de paz foi sendo gradativamente reduzida, encontrando-se atualmente restrita à habilitação e celebração dos casamentos (art. 144, §1ำ da Constituição de 1967) 
A Constituição de 5 de outubro de 1988 pretende dar novo alento a instituição, ao dispor que a União, no Distrito Federal e nos Territórios, e os Estados criarão a "justiça de paz, remunerada, composta de cidadãos eleitos pelo voto direto, universal e secreto, com mandato de quatro anos e competência para, na forma da lei, celebrar casamentos, verificar, de ofícios ou em face de impugnação apresentada, o processo de habilitação e exercer atribuiçōes conciliatórias, sem caráter jurisdicional, além de outras previstas na legislação". (art. 98, II)

Será, possivelmente, mais uma forma de tornar a justiça mais acessível e próxima do povo, anseio que, como se viu, constitui tradicional preocupação em nosso direito.

Por outro lado, sempre será oportuno realçar o significado da conciliação, instituição provinda dos primórdios do cristianismo e do mais antigo Direito Carônico, ("Não causarás cismas, mas reconciliarás os que lutam entre si", "Didaqué" ou "Doutrina dos Doze Apóstolos", 4, 3, fim do século II) e que se amoldaria no Direito Comum, para passar às codificaçōes lusitanas, tanto que estavam os juízes incumbidos de dizer às partes "que antes que fizessem despesas e seguissem entre elas os ódios e dissenssōes, que concordassem, e não gastassem suas fazendas por conta de suas vontades, porque o vencimento das causas sempre era duvidoso". (ORD. FIL. LIV. III, TIT. XX, 1; ORD. MAN, LIV. III, TIT. XV, 1; ORD. AF. LIV. III, TIT. XX, 5)

Possa a desembocadura do juizado especial de pequenas causas, realidade presente, (Lei no 7.244, de 7.11.84) representar o resultado deste esforço desenvolvido no passado, oferecendo também aos mais humildes, a justiça que a todos por direito cabe.

São Paulo, fevereiro de 1988. 